\title{
YACON INULIN LEACHING DURING HOT WATER BLANCHING
}

\author{
Dissolução de inulina do yacon durante o branqueamento em água quente
}

\author{
Caroline Fenner Scher ${ }^{1}$, Adriano Brandelli ${ }^{1}$, Caciano Zapata Noreña ${ }^{2}$
}

\begin{abstract}
Yacon roots contain inulin, which has prebiotic properties and it may be used as sucrose or fat substitutes. However, inulin is very soluble in water. The loss of this important nutrient during blanching is caused mainly by diffusion or leaching, which might be diminished if blanching temperature - time conditions are correctly employed. The aim of this study was to determine the leaching of the sugars inulin, glucose and fructose, present in yacon roots, during hot water blanching under different time/temperature conditions. The samples were cleaned and peeled and cut into geometric forms of $1.75 \pm 0.35 \mathrm{~mm}$ thick disks. A complete factorial experimental design was used, and the treatments of the samples were compared using the Tukey test. The results indicated that the time and temperature were significant in the dissolution of the sugars. The lowest inulin losses occurred at temperatures and times lower than $60^{\circ} \mathrm{C}$ and 3 minutes. For all temperatures, the lowest glucose and fructose losses were obtained at time lower than 3 and 5 minutes, respectively.
\end{abstract}

Index terms: Glucose; fructose; prebiotic; response surface.

\section{RESUMO}

As raízes de yacon contém inulina, o qual possui propriedade prebiótica e pode ser usado como substituto de sacarose ou gordura. Entretanto, a inulina é solúvel em água. As perdas desse nutriente durante o branqueamento são causadas, principalmente, por difusão ou lixiviação, o qual pode ser diminuído se as condições de tempo e temperatura são corretamente empregadas. Objetivou-se neste trabalho, foi estudar a lixiviação, durante o branqueamento em água quente em diferentes condições de tempo e temperatura, dos açúcares inulina, glicose e frutose presentes na raiz do yacon. As amostras foram previamente limpas, descascadas e cortadas na forma geométrica de disco de 1,75 \pm 0,35 milímetros de espessura. Os resultados indicaram que o tempo e a temperatura foram significativos na dissolução dos açúcares. As menores perdas de inulina ocorreram à temperaturas e tempos menores que $60^{\circ} \mathrm{C}$ e 3 minutos, respectivamente, enquanto que as menores perdas de glicose e frutose, para todas as temperaturas, foram obtidas para tempos menores que 3 e 5 minutos, respectivamente.

Termos para indexação: Glicose; frutose; prebiótico; superfície de resposta.

\section{INTRODUCTION}

Yacon (Smallanthus sonchifolius) is a perennial plant belonging to the Asteraceae family, which originated in the Andes Mountains and presents a relatively low energy value despite its sweet taste (Cazetta et al., 2005). Nakanishi (1997) reported that the yacon was introduced into Japan in 1985 and arrived in Brazil at the beginning of the nineties (Moscatto; Prudêncio-Ferreira; Hauly, 2004).

The yacon roots, similar to those of artichokes and of the Jerusalem artichoke, are tubers, similar to the sweet potato in appearance, and normally have a sweet taste due to an abundance of soluble carbohydrates such as fructose, glucose, sucrose and fructooligosaccharide or inulin (Grau; Rea, 1997), the main carbohydrate present in the yacon being the sugar in the form of fructooligosaccharides (FOS) (Hermann; Freire; Pazos, 1999).

Some authors recommend the consumption of yacon by diabetic individuals and those with digestive problems, since its sugars are not digested in the small intestine (Lachman; Fernandez; Orsa'K, 2003). In addition, FOS promote other health benefits for humans, such as a reduction of high cholesterol levels and as an aid in the prevention of some types of cancer (Passos; Park, 2003).

The yacon root deteriorates easily and shows rapid browning of its juice and of its tissues when handled badly, caused by some mechanical damage to the product (Neves; Silva, 2007) or during processing and/or storage (Lachman; Fernandez; Orsa'K, 2003). One of the methods employed in the inactivation of the enzymes responsible for browning is the use of heat transfer operations. Hot

\footnotetext{
${ }^{1}$ Universidade Federal do Rio Grande do Sul/UFRGS - Porto Alegre - RS - Brasil

2Universidade Federal do Rio Grande do Sul/UFRGS - Av. Bento Gonçalves - 9500 - Bairro Agronomia - Porto Alegre - RS - Brasil - czapatan@ufrgs.br Received in april 13, 2015 and approved in june 2, 2015
} 
water blanching is a simple and economic unit operation, although prolonged residence times result in a considerable loss of nutrients, such as carbohydrates, proteins minerals, vitamins and water-soluble sugars (Lee, 1958). Kramer and Smith (1947) reported that the loss of important nutrients during blanching is caused mainly by diffusion or leaching.

Some works on blanching in yacon were found in the literature. Fante et al. (2013) found that using different times of steam blanching, the best condition was with a time of $4 \mathrm{~min}$, where it was possible to reduce the activity of polyphenoloxidase and peroxidase 84.62 and $83.76 \%$, respectively, with losses of inulin, glucose and fructose of $30.69,39.40$ and $15.82 \%$, respectively. Reis, Lenzi and Masson (2012) studied the effect of varying yacon tuber slice thickness and its immersion at different concentration solutions of citric acid on color and texture during vacuum drying, finding that the product quality features were significantly affected for adding acid.

A considerable amount of research has been done to study the effects of blanching on texture, colour, phytochemical content and enzymatic activity of different vegetables and fruits. However, data on the effect of blanching on leaching of sugars is scarce. The objective of this work was to study dissolution of the sugars inulin, glucose and fructose present in yacon during hot water blanching.

\section{MATERIAL AND METHODS}

\section{Material}

Yacon roots (Smallanthus sonchifolius), produced in the State of São Paulo, Brazil, were acquired from the Central Supply Station (Ceasa) in the city of Porto Alegre (State of Rio Grande do Sul, Brazil). The fruits were washed and selected considering the absence of visual damage and infection, and also uniformity of size and color, and were subsequently stored under refrigeration $\left(8 \pm 2{ }^{\circ} \mathrm{C}\right)$ up to the moment of use.

\section{Experimental procedure}

The yacon roots were peeled and cut in a form of disks with an average diameter of $4.55 \pm 0.25 \mathrm{~mm}$ and a thickness of $1.75 \pm 0.35 \mathrm{~mm}$. The disks were submitted to blanching consisting of total immersion in water with different time/temperature combinations. After blanching, the excess water was removed and the samples cooled rapidly in cold water $\left(0-4{ }^{\circ} \mathrm{C}\right)$ for 3 minutes (Agüero; Ansorena; Roura, 2008). The samples were placed in plastic packages and frozen for subsequent analysis of the sugars by HPLC.

\section{Sample preparation for determination of the sugars}

The samples were prepared using an adaptation of the method described by Toneli et al. (2007), used for the extraction of inulin from chicory roots. Ten grams $(10 \mathrm{~g})$ of frozen blanched sample were ground with $50 \mathrm{~mL}$ hot deionized water at $90^{\circ} \mathrm{C}$ (to better extract the inulin) using a multi food processor. The mixture was then heated in a water bath at $80^{\circ} \mathrm{C}$ for 1 hour with constant stirring in an IKA stirrer, model RW20. The suspension was then cooled to room temperature and centrifuged for 15 minutes at $1680 \mathrm{~g}$ and $25^{\circ} \mathrm{C}$ in a Hermle $\mathrm{Z} 323 \mathrm{~K}$ centrifuge. The supernatant was first filtered through Whatman $\mathrm{n}^{\circ} 1$ filter paper and then through a $22 \mu \mathrm{m}$ membrane filter. The filtrates were frozen and stored at $-18^{\circ} \mathrm{C}$. For the analyses, the frozen samples were pre-heated at $80{ }^{\circ} \mathrm{C}$ and then placed in a Thorton ultra-sound bath for 10 minutes for subsequent injection into the HPLC.

\section{Determination of the sugar concentrations by HPLC}

The inulin, glucose and fructose contents of the yacon samples were determined by an adaptation of the method described by Zuleta and Sambucetti (2001) for the direct determination of sugars by high performance liquid chromatography. A Perkins Elmer series 200 chromatograph was used, equipped with a refractive index detector, Milli-Q water as the mobile phase at $0.6 \mathrm{~mL} / \mathrm{min}$, temperature of $80{ }^{\circ} \mathrm{C}$ and a $300 \times 7.8 \mathrm{~mm}$ Phenomenex Rezex RHM monosaccharide column. The total run time was 13 minutes. The retention time for inulin was 6.9 minutes, for glucose 9.7 minutes and for fructose 10.4 minutes. All the determinations were carried out in duplicate.

\section{Statistical analysis}

Table 1 shows the experimental design used to study the dissolution of the sugars (inulin, glucose and fructose). A random complete factorial design was used, and the treatments for the samples compared using the Tukey means test.

The SAS 6.3 program (SAS Institute, 1993) was used for the statistical tests.

\section{RESULTS AND DISCUSSION}

\section{Dissolution of inulin, glucose and fructose from yacon}

The initial percentage of inulin in the yacon was $9.25 \pm 0.44 \%$ on a dry weight basis, in agreement with the data of Cazetta et al. (2005) and Gibson, Willis and Loo (1994), who found, respectively, values between 3-10\% and $3-19 \%$ for inulin in yacon roots. With respect to the fructose and glucose contents, the values found were 
$50.28 \pm 0.73 \%$ and $22.8 \pm 0.82(\mathrm{dwb})$. Cabello (2005) reported values of $48.3 \%$ and $24.9 \%$ for fructose and glucose, respectively.

For the treatments studied, the ANOVA (Table 2) indicated that the effects of temperature and time and the interaction between them were significant for inulin and glucose, whereas only the principal effects (time and temperature) were significant for fructose.

In order to better explain on the effect of two factors and their interaction, the contour curves and response surfaces were elaborated. For inulin (Figure 1), the ANOVA of the quadratic regression model demonstrated that the model was significant, as was evident from the F-test with a very low probability value $(p<0.05)$. The coefficient of determination $\left(R^{2}=0.92\right)$ was satisfactory and confirmed the significance of the model. Figure 1 shows that the longer the immersion time and the higher the temperature, the greater the dissolution of inulin, corresponding to a joint effect between time and temperature. According to both Figures $1 \mathrm{a}$ and $1 \mathrm{~b}$ the time and temperature of blanching affected loss of inulin. This might be explained by that the mass transfer is slow at low temperatures and dissolution of inulin outside the yacon required more time to dissolve into the solution. However, at higher temperature the sugars dissolution reached equilibrium in a short time. It was also observed that during the first 15 minutes there was a linear relationship between the time and the temperature, but then this relationship is not anymore linear.

The lowest inulin loss occurred at temperature lower than $60{ }^{\circ} \mathrm{C}$ before 3 minutes exposure $(\mathrm{p}<0.05)$. Thermal processing of vegetables has pronounced effects on the cell structure, often negatively affecting the final textural properties of the product, and texture changes upon blanching and cooking are mainly related to the gelification of pectins located in the cell walls as well as their solubilization and degradation (Neri et al., 2011). In agreement with Paredes et al. (2007), the cell damages determined by the blanching treatment cause a decrease of the resistance to mass transfers and, thus, favor the loss of water and/or solutes from the vegetable matrix.

Table 1: Experimental design for the response surface analysis.

\begin{tabular}{ccc}
\hline Treatment & Temperature $\left({ }^{\circ} \mathrm{C}\right)$ & Time $(\mathrm{min})$ \\
\hline 1 & 50 & 15 \\
2 & 50 & 5 \\
3 & 70 & 15 \\
4 & 70 & 5 \\
5 & 60 & 17 \\
6 & 60 & 3 \\
7 & 74 & 10 \\
8 & 46 & 10 \\
9 & 60 & 10 \\
10 & 90 & 1 \\
11 & 90 & 2 \\
\hline
\end{tabular}

Table 2: Analyses of variance for the dissolution of sugars during the blanching of yacon.

\begin{tabular}{cclcc}
\hline Sources of variation & Degrees of freedom & Inulin & Glucose & Fructose \\
\hline Temperature $(\mathrm{T})$ & 5 & $1.843^{*}$ & $75.911^{*}$ & $441.767^{*}$ \\
Time $(\mathrm{t})$ & 4 & $4.707^{*}$ & $167.341^{*}$ & $867.495^{*}$ \\
$\mathrm{~T} \times \mathrm{t}$ & 1 & $0.475^{*}$ & $0.588^{*}$ & 1.155 \\
Error & 15 & 0.104 & 1.487 & 6.017 \\
Total & 25 & 7.130 & 245.327 & 1316.434 \\
\hline
\end{tabular}

* Significant at the 5\% level. 
Vendrell-Pascuas, Castellote-Bargalló and López-Sabater (2000) mentioned that pure inulin is practically insoluble in cold water but easily soluble in hot water. Kim, Faqih and Wang (2001), in a study on the formation of an inulin gel, showed that inulin was practically insoluble at $25{ }^{\circ} \mathrm{C}$, and at $50{ }^{\circ} \mathrm{C}$ only $1.2 \%$ soluble, but increasing temperatures resulted in a significant rise in solubility, reaching $34 \%$ at $90{ }^{\circ} \mathrm{C}$. In addition to contributing to an increase in solubility of the sugars, high temperatures also damaged the cell system, allowing the intracellular sugar to migrate quickly into the medium. According to Halpin and Lee (1987), blanching modifies the physical properties of the tissues due to the heat destruction of the cell membrane.

For glucose, Figure 2 (the regression model demonstrated that the model was significant due to $p<0.05$ and $R^{2}=0.93$ ) shows the contour curves and response surfaces indicating the effects of increasing the time and temperature on the loss of glucose to the medium. In this case also is observed that the temperature and the time of blanching affected loss of reducing sugar. As expected, both the variables were inversely correlated to the leaching of sugars.

According to both figures, glucose content increased linearly with a diminution of temperature for times less than 5 minutes, but for times higher than 6 minutes decreased curvilinearly with an increase in time for all temperatures.
For fructose, Figure 3 (the fitting model was significant with $p<0.05$ and $R^{2}=0.94$ ) also indicate that the greater the time and the temperature used in blanching, the greater the dissolution of fructose in the medium. According to both Figures $3 a$ and $3 b$, the influence of the time of treatment on loss of reducing sugar was higher than the influence of the temperature. It is well evident that it is necessary to apply less temperature-time combinations to obtain less loss of sugars. Both variables resulted in a curvilinear decrease in fructose content when all combination temperatures times employed increase.

Our results showed that lowest glucose and fructose losses were obtained at times lower than 3 and 5 minutes, respectively $(\mathrm{p}<0.05)$. Garrote, Bertone and Silva (1984) found that an increase of temperature, in potato slices during water blanching, produced a higher glucose loss, particularly between 55 and $65^{\circ} \mathrm{C}$. Bartolome and Hoff (1972) also reported that, in the $50-70{ }^{\circ} \mathrm{C}$ range, cellular membranes have a special thermal lability causing cytoplasmic and vacuole solutes to diffuse into intercellular spaces. Towards $70{ }^{\circ} \mathrm{C}$, pectin methylesterase is activated, producing an increased resistance of the tissue to further thermal degradation. A possible consequence of this latter modification may be a much lower increase in the apparent diffusivity for glucose over the $65-85{ }^{\circ} \mathrm{C}$ temperature range (Garrote; Bertone; Silva, 1984).
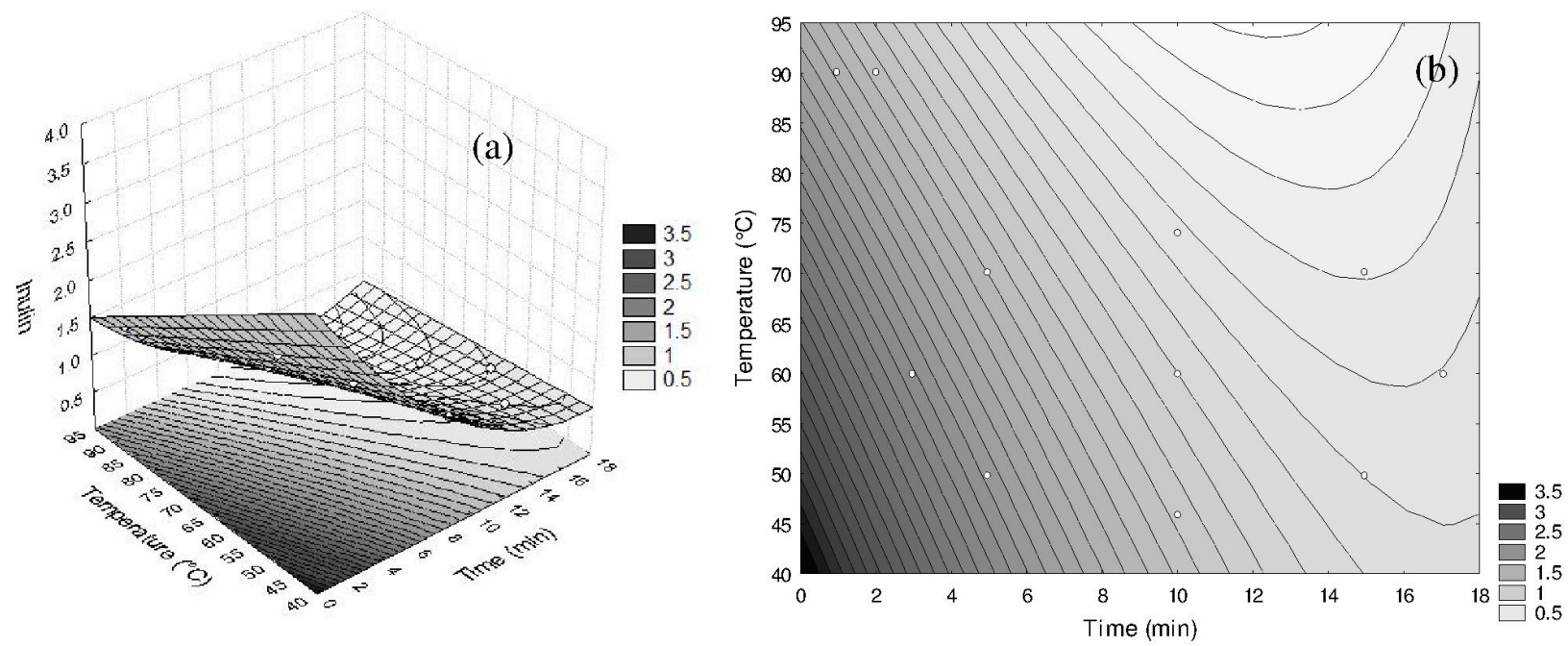

Figure 1: Response surface (a) and contour plots (b) for the effects of water temperature and immersion time on the inulin concentration from yacon samples cut in the form of disks.

Ciênc. Agrotec., Lavras, v. 39, n. 5, p. 523-529, set./out., 2015 

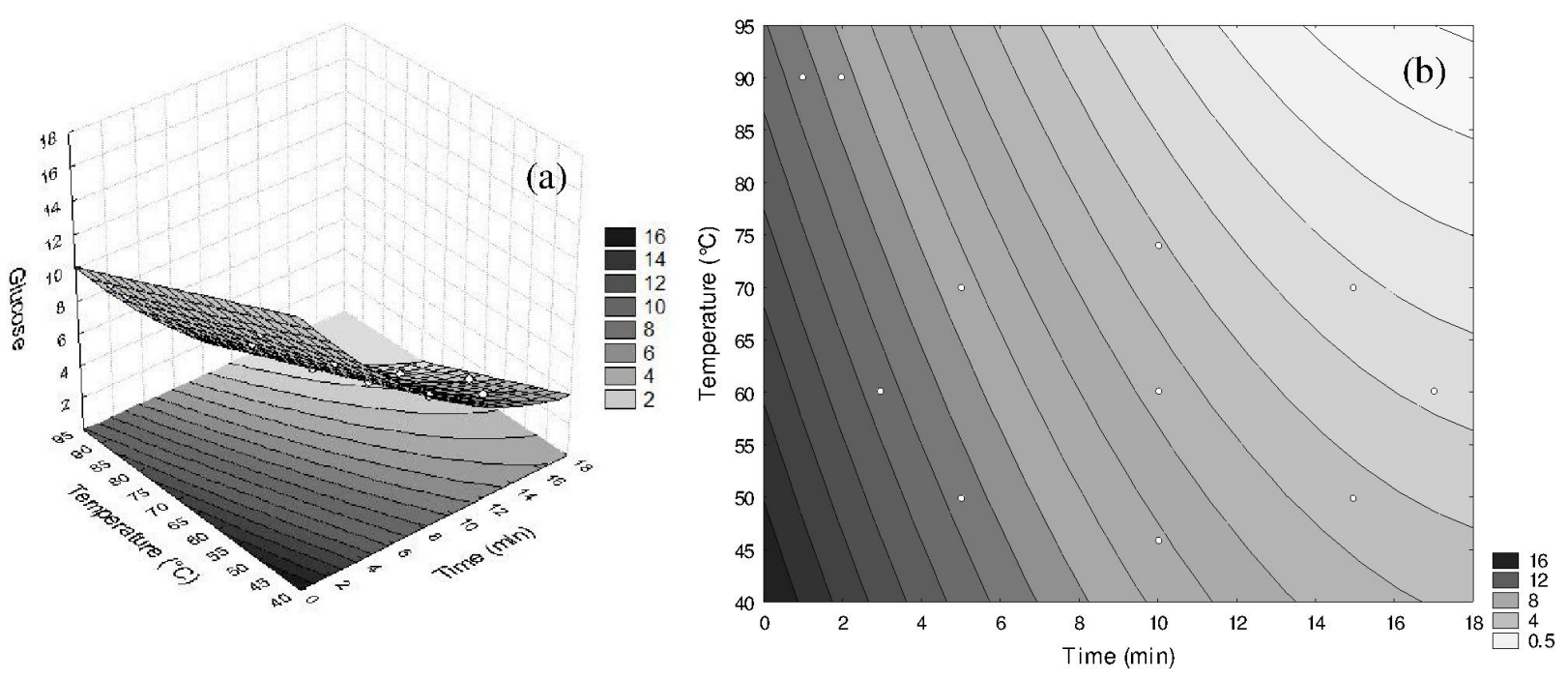

Figure 2: Response surface (a) and contour plots (b) for the effects of water temperature and immersion time on the glucose concentration from yacon samples cut in the form of disks.
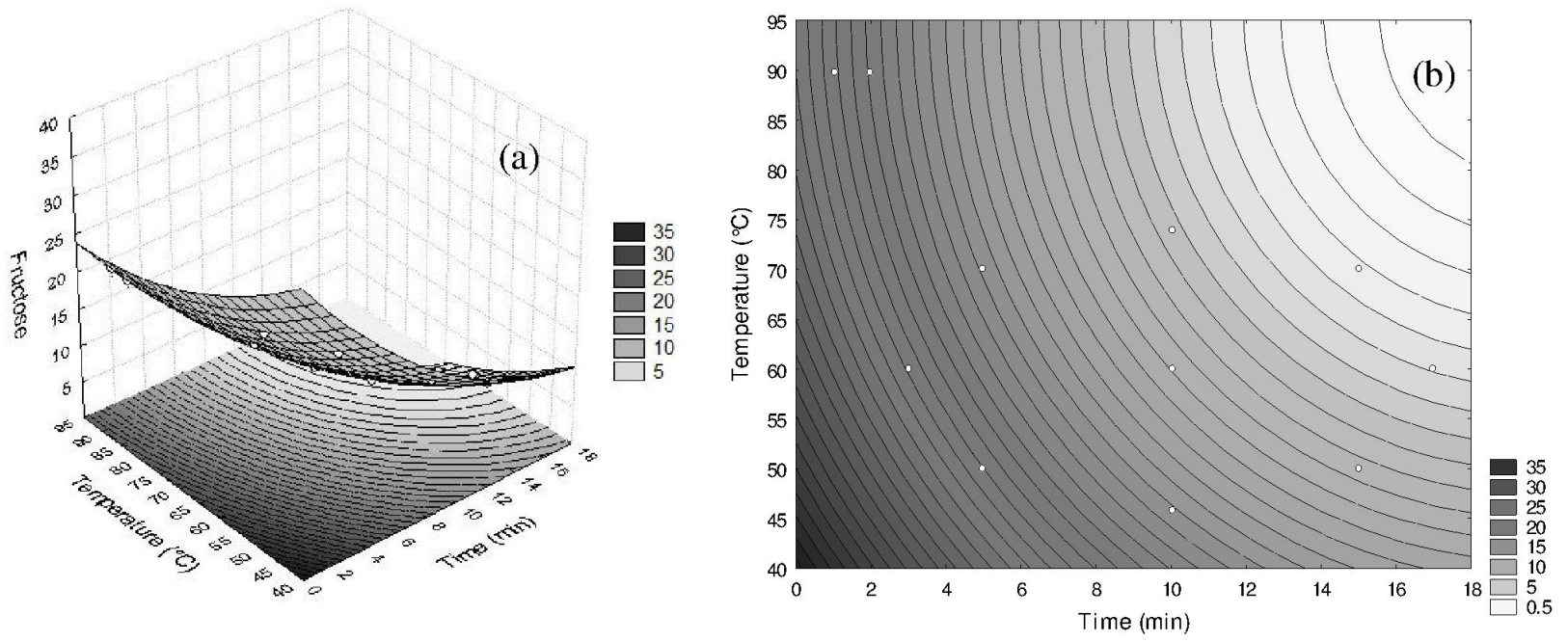

Figure 3: Response surface (a) and contour plots (b) for the effects of water temperature and immersion time on the fructose concentration from yacon samples cut in the form of disks.

As can be observed, in the different conditions there was high dissolution of sugars, this was due to the fact that the samples were cutting up into little thick, and therefore the diffusion time of the water into the sample was shorter, allowing for greater dissolution of the sugars in the matrix, resulting in greater losses. In addition, a quicker loss of firmness of the vegetable tissue contributed to the loss of solutes (Anderson et al., 1994).
Mukherjee and Chattopadhyay (2007) mentioned that during the blanching of potatoes in the form of cubes in hot water at 93 and $100{ }^{\circ} \mathrm{C}$ for 3 minutes, the loss of reducing sugars was 51 and 54\%, respectively. Pedreschi et al. (2009) blanched potatoes cut into $2.5 \mathrm{~mm}$ thick disks at temperatures of 60,75 and $90^{\circ} \mathrm{C}$, and showed losses of reducing sugars of $61.7,80$ and $84 \%$, respectively, in 120 minutes. In the present study, the samples lost 65 and $62.7 \%$ of glucose and fructose, respectively, when heated at $90{ }^{\circ} \mathrm{C}$ for 2 minutes. Saldivar 
et al (2010) also found that in soybean seeds blanched in water had significantly loss of glucose, fructose, sucrose and raffinose sugars content and this was attributed to the water used which solubilized sugars and led part of soluble sugars from leaching out during water blanching.

Regarding the possibility of cleavage during blanching, Matusek et al. (2011) found that fructooligosaccharides had strong degradation occurred at $70-80{ }^{\circ} \mathrm{C}$ in $\mathrm{pH}$ range $2.7-3.3$. However, L'Homme et al. (2003) mention that the degradation process of oligosaccharides takes place much more easily at acidic $\mathrm{pH}$ than at neutral or basic $\mathrm{pH}$ values. In our study the $\mathrm{pH}$ value of yacon was $6.09 \pm 0.01$.

\section{CONCLUSIONS}

In the blanching of yacon in the form of disks, the leaching of the sugars inulin and glucose the time, temperature and the interaction between them were all significant, and for fructose only the time and temperature were significant. The lowest inulin losses occurred at temperatures and times lower than $60^{\circ} \mathrm{C}$ and 3 minutes. For all temperatures, the lowest glucose and fructose losses were obtained at time lower than 3 and 5 minutes, respectively. In order to preserve inulin in yacon, it is recommended using steam blanching in future studies.

\section{AKNOWLEGDEMENTS}

The authors are grateful to FAPERGS (Foundation for Research Support of Rio Grande do Sul State) and to $\mathrm{CNPq}$ (Brazilian National Research Council) for the financial support.

\section{REFERENCES}

AGÜERO, M.R.; ANSORENA, S.I.; ROURA, C.E.V. Thermal inactivation of peroxidase during blanching of butternut squash. LWT - Food Science and Technology. 41:401-407, 2008.

ANDERSON, A. et al. Effect of preheating on potato texture. Critical Reviews in Food Science and Nutrition. 34:229-251, 1994.

BARTOLOME, L.G.; HOFF, J.E. Firming of potatoes. Biochemical effects of pre-heating. Journal of Agricultural and Food Chemistry. 20:266-270, 1972.

CABELLO, C. Extração e pré-tratamento químico de frutanos de yacon (Polymnia sonchifolia). Ciência e Tecnologia de Alimentos. 25:202-207, 2005.
CAZETTA, M.L. et al. Yacon (Polymnia sanchifolia) extract as a substrate to produce inulinase by Kluyveromyces marxianus var. bulgaricus. Journal of Food Engineering. 66:301-305, 2005.

FANTE, L. et al. Study of enzyme inactivation using steam in yacon (Smallanthus sonchifolius) roots.

Journal of Food Processing and Preservation. 37:1624, 2013.

GARROTE, R.L.; BERTONE, R.A.; SILVA, E.R. Effect of soaking-blanching conditions on glucose losses in potato slices. Canadian Institute of Food Science and Technology Journal. 17:111-113, 1984.

GIBSON, G.R.; WILLIS, C.; LOO, J.V. Non-digestible oligosaccharides and bifidobacteria: implications for health. International Sugar Journal. 96:381-387, 1994.

GRAU, A.; REA, J. Yacon [Smallanthus sonchifolia (Poepp. Et Endl.) H. Robinson]. Andean roots and tuberous roots: ahipa, arracacha, maca and yacon. In: Promoting the Conservation and use of underutilized crops. Hermann, M.; Heller, J., Eds.; IPK, Gatersleben/ IPGRI: Rome. 174:199-256, 1997.

HALPIN, B.E.; LEE, C.Y. Effect of blanching on enzyme activity and quality changes in green peas. Journal of Food Science. 52:1002-1005, 1987.

HERMANN, M.; FREIRE, I.; PAZOS, C.

Compositional diversity of the yacon storage root. In: Impact on a changing world. Program Report 1997-1998. Centro Internacional de La Papa (CIP), Lima, Peru. 425-432, 1999. 457p.

KRAMER, A.; SMITH, M.H. Effect of duration and temperature of blanch on proximate and mineral composition of certain vegetables. Industrial \& Engineering Chemistry. 39:1007-1009, 1947.

KIM, Y.; FAQIH, M.N.; WANG, S.S. Factors affecting gel formation of inulin. Carbohydrate Polymers. 46:135-145, 2001

LACHMAN, J., FERNANDEZ, E.C.; ORSA'K, M. Yacon [Smallanthus sonchifolius (Poepp. Et Endl.) H. Robinson] chemical composition and use - A review. Plant, Soil and Environment. 49:283-290, 2003. 
LEE, F.A. The blanching process. Advances in Food Research. 8:63-109, 1958.

L'HOMME, C. et al. Kinetics of hydrolysis of fructo-oligosaccharides in mineral-buffered aqueous solutions: Influence of $\mathrm{pH}$ and temperature. Journal of Agricultural and Food Chemistry. 51: 224-228, 2003.

MATUSEK, A. et al. Fructo-oligosaccharide degradation in apple pulp matrix. Acta Alimentaria. 40: 182-193, 2011.

MOSCATTO, J.A.; PRUDÊNCIO-FERREIRA, S.H.; HAULY, C.O.M. Farinha de yacon e inulina como ingredientes na formulação de bolo de chocolate.

Ciência e Tecnoogia de Alimentos. 24:634-640, 2004.

MUKHERJEE, S.; CHATTOPADHYAY, P.K. Whirling bed blanching of potato cubes and its effects on product quality. Journal of Food Engineering. 78:52-60, 2007.

NAKANISHI, T. Cultivation of yacon. Nogyo oyobi Engei. 72: 44-50, 1997.

NERI, L. et al. Effect of blanching in water and sugar solutions on texture and microstructure of sliced carrots. Journal of Food Science. 76:E23-E30, 2011.

NEVES, V.A.; SILVA, M.A. Polyphenol oxidase from yacon roots (Smallanthus sonchifolius). Journal of Agricultural and Food Chemistry. 55:2424-2430, 2007.

PASSOS, L.M.L.; PARK, Y.K. Frutooligossacarídeos: implicações na saúde humana e utilização em alimentos. Ciência Rural. 33:385-390, 2003.
PAREDES, E.M. et al. Effect of long-term storage and blanching pre-treatments on the osmotic dehydration kinetics of carrots (Daucus carota L. cv. Nerac).

Journal of Food Engineering. 81:313-317, 2007.

PEDRESCHI, F. et al. Kinetics of extraction of reducing sugar during blanching of potato slices. Journal of Food Engineering. 91:443-447, 2009.

REIS, F.R.; LENZI, M.K.L.; MASSON, M.L. Effect of vacuum drying conditions on the quality of yacon (Smallanthus sonchifolius) slices: process optimization toward color quality. Journal of Food Processing and Preservation. 36:67-73, 2012.

SAS Institute. STAT Guide for Personal Computers. Cary: Statistical Analysis System Institute, 1993.

SALDIVAR, X. et. al. Effects of blanching and storage conditions on soluble sugar contents in vegetable soybean. LWT - Food Science and Technology. 43:1368-1372, 2010.

TONELI, J.T.C.L. et. al. Optimization of a physical concentration process for inulin. Journal of Food Engineering. 80:832-838, 2007.

VENDRELL-PASCUAS, S.; CASTELLOTEBARGALLÓ, A.I.; LÓPEZ-SABATER, M.C.

Determination of inulin in meat products by highperformance liquid chromatography with refractive index detection. Journal of Chromatography A. 881:591-597, 2000.

ZULETA, A.; SAMBUCETTI, M.E. Inulin Determination for Food Labeling. Journal of Agricultural and Food Chemistry. 49:4570-4572, 2001. 
